\title{
染料移行昇華防止のための 繊維表面の化学処理
}

\section{天 野 慈 朗*}

\author{
Chemical Treatments of Fabric Surface \\ for Prevention of Staining Caused by Dye Migration
}

Jiro AMANO*

Key Words : Chemical Treatment, Fabric Surface, Coating, Dye Migration, Polyester Fiber

ポリエステル繊維コーティング加工布における分散染料の移行昇華污染の機構と従来の防止技術を概 説するとともに，化学反応を利用した新しい防止技術について紹介する。

\section{1.はじめに}

現在，レインコート，スキーウェア，傘地などの各種 防水布に利用されているコーティング加工用の布帛は, ナイロン織維を主体とする織編物が中心である。ナイロ ン緘維の持つしなやかさ，風合い，色の鮮やかさなどが 好まれていることあ事実であるが，コスト，寸法安定性， 強度，耐光性，素材の多様性などに優位性を有するポリ エステル緘維が，なぜコーティング加工用の布帛として 多用されないのであろうか。その最す大きな理由の $1 つ$ は，ポリエステル緘維が分散染料の移行昇華污染という 致命的な問題点を抱えているからであると言われている。

ポリエステル㵶維が，上述したような優位性のために 他の用途において広い範井にわたってナイロン繊維に取っ て代わっていることは公知の事実である。そうした流れ にあ拘わらず，今なおナイロン繊維が主力素材となって いる分野が存在しているのあ，また事実である。ポリエ ステル織維を中心に研究しているものにとって，このよ うな分野が存在しているということは，そこにポリエス テル繊維の弱点を見ることができる。言葉を換えると， そこに研究の種があるということになる。

ポリエステル緘維の染料移行昇華污染もそうした弱点 の1つである。こうした弱点を改善しようとここれだ にあポリエステル繊維の表面改質を始め, 種々の試みが なされてきた。今回，「織維の表面処理による高機能化」 と題する小特集に, 繊維表面の化学処理に関連する技術 の紹介をということで寄稿の要請を受けた。コーティン

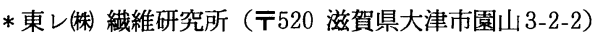

Fibers \& Textiles Res. Lab., Toray Industries, Inc. (2-2, Sonoyama 3-chome, Otsu-shi, Shiga 520)
}

グ加工が化学処理と言えるかどうか，やや主旨からは外 れるかもしれないが，化学反応を利用した前処理技術や 化学構造を考慮した樹脂設計をむ含めて, 広く化学加工 とご理解いただきたい。

本稿では, ポリエステル繊維における分散染料の移行 昇華污染の機構と，これまでに行われてきた染料移行昇 華污染防止技術を概説するとともに，筆者らが新しく開 発した染料移行昇華污染防止コーティング技術について 紹介する。

\section{2. 分散染料の移行昇華污染の機構}

ポリエステル繊維において，一般的に言われる分散染 料の移行昇華污染とは, 分散染料で染色されたポリエス テル繊維布帛からアイロンなどの熱によって分散染料が 昇華し，他の織維布帛へ移行污染する現象をいう。

ナイロン繊維や天然繊維など特定の染着座席を持つ繊 維の染色とは異なり，ポリエステル䋐維は染着座席を持 たないため，水に分散させた分散染料を約 $130^{\circ} \mathrm{C}$ とう 高温高圧の条件で繊維内部に吸尽させることにより染色 を行っている。しかし，繊維内部に吸尽された分散染料 は，ナイロン繊維に扔ける末端アミノ基と酸性染料との イオン結合のように，ポリエステル分子と特別な化学結 合により結合しておらず，高温の熱処理によって容易に 繊維内部を移行拡散する。また，分散染料は，わずかで はあるが高温で蒸気圧を有するため，高温で熱処理され るとポリエステル緘維から昇華によって脱落してしまう。 特に, 濃色のポリエステル繊維と淡色のポリエステル緘 維が接触しているような場合, 濃色のポリエステル䋐維 から昇華した分散染料が淡色のポリエステル䋐維に移行 し，これが污染となって顕在化するのが分散染料の移行 


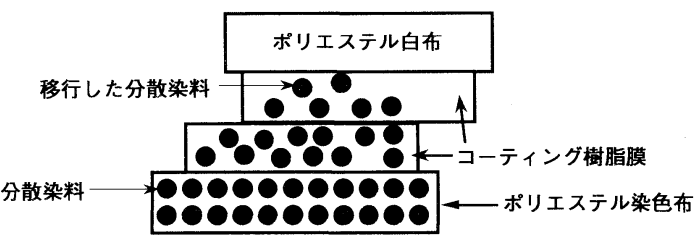

図 1 ポリエステル繊維コーティング加工布における分散染料 移行昇華污染のイメージ図

昇華污染である。

この現象は，分散染料がその構造上多かれ少なかれ昇 華性を有するために避けがたいが，染工場などではでき る限り昇華性の小さい染料を選択することによって，ほ ぼ実用上問題ないレベルまで改善している。

ところが，このような染料選択を行って移行昇華性の 小さい分散染料を用いて染色したポリエステル繊維布帛 においても，ポリウレタン樹脂やアクリル樹脂によるコー ティング加工を行うと，図１に示すようにコーティング 面を介して分散染料の移行昇華污染という問題が発生す る。すなわち，コーティング加工布帛における分散染料 の移行昇華污染は，一般に言われるポリエステル繊維の 移行昇華污染とは異なる現象なのである。

そこで，筆者らは，コーティング加工工程中における 樹脂皮膜中の分散染料の動きに注目して，分散染料の移 行昇華污染の機構を調べてみた。

湿式コーティング加工の一般的な加工工程は，(1) ポ リウレタン樹脂などをナイフコーターにより布帛片面に コーティングするコーティング工程，(2) 水などの凝固 浴中で湿式凝固する凝固工程，(3) 溶媒などを除去する 水洗工程, (4) 乾燥工程, (5) 撥水剤などを付与後高温熱 処理により架橋するキュア工程からなる。ポリエステル 繊維中の分散染料は，コーティング工程において，一部 樹脂溶媒であるジメチルホルムアミド（DMF）などに 溶解して樹脂溶液層に溶出するが，凝固工程，水洗工程 において溶媒が水と置換され，除去されるため，実質的 にはわずかにしか樹脂膜中には残存しない。

ところが, その後の乾燥工程, キュア工程と熱処理を 受けることによって, 分散染料はポリエステル繊維より あ親和性の高い樹脂膜中へ徐々に熱拡散し，キュア工程 を出た時点では，ほとんど樹脂膜全体に拡散し，膜表面 にまで達していることがわかった。すなわち，製品となっ たコーティング加工布帛においては，樹脂膜中に多くの 分散染料が存在し，熱転写によって容易に移行できる状 態となっているのである。

これに対して乾式コーティングの場合は，また異なっ た移行挙動を示す。乾式コーティング加工の一般的な加 工工程は，(1)アクリル樹脂などをナイフコーターなど
により布帛片面にコーティングするコーティング工程, (2) 樹脂の溶媒を揮散させる乾燥工程, (3) 撥水処理の後 に樹脂の架橋を行わせるキュア工程からなる。ポリエス テル繊維中の分散染料は，樹脂溶媒であるトルエンなど によって容易に抽出され，乾燥工程の熱によって溶媒中 を拡散し，溶媒がほぼ完全に揮散した乾式凝固膜の形成 段階では，ほとんど樹脂膜全体に拡散し，キュア工程を 出た時点では，膜表面にまで達していることがわかった。 すなわち, 分散染料の加工工程中における移行挙動は湿 式コーティングの場合と異なるあのの, 製品となったコー ティング加工布帛においては，同様に樹脂膜中に多くの 分散染料が存在し，熱転写によって容易に移行できる状 態となっているのである。

このように，ポリエステル繊維コーティング布帛にお ける分散染料の移行昇華污染は，湿式コーティングでは, 熱拡散により樹脂膜中に移行した分散染料が，乾式コー ティングでは，溶媒への溶解拡散により樹脂膜中に移行 した分散染料がそれぞれ引き金となって起こるのである が，最終製品として考えた場合には，いずれあ樹脂膜中 の分散染料が熱転写によって他の樹脂膜へ転写される現 象である。したがって，ポリエステル繊維コーティング 加工布帛に抢ける染料移行昇華污染は, 正確に言えば, 構造のルーズな樹脂層に存在する分散染料の移行昇華が 原因となって発生しているのである。

\section{3. 染料移行昇華污染防止の従来技術}

これまでに提案されているポリエステル繊維コーティ ング加工布帛における染料移行昇華污染防止の考え方は 次の 2 つに大別される。

(1) 繊維から樹脂層への染料移行を抑制する方法

(2) 樹脂層の染料拡散を抑制する方法

第 1 の考え方は，コーティングを行う前に繊維表面に分 散染料の移行阻止膜を形成させ，コーティング工程での 分散染料のコーティング樹脂膜への移行を抑制しようと するあのである。この考え方の代表例と言えるのが，分 散染料が透過できないち密なメラミンなどの架橋樹脂膜 を形成させる方法 ${ }^{1)}$ である。メラミンの架橋皮膜を単 繊維表面に形成させる技術は，もともと難溶融加工とし て古くから知られた技術であるが，非常にち密な膜が形 成され，分散染料の移行昇華を抑制できることからコ一 ティング加工の前処理として利用されたあのである。メ チロールメラミンなどの熱架橋反応を利用し，湿熱処理 を行うことにより，繊維間隙への樹脂の凝集を抑え，単 繊維表面に効率よく架橋皮膜を形成させる要素技術であ る。移行昇華污染の原因を元から絶つことができるため, 染料移行昇華污染防止効果は非常に高いが, 特殊な別工 程が必要であるためコスト高であり，風合いが硬くなる， ホルマリンが発生するなどの課題が残されている。 
また，分散染料と親和性のない親水性の樹脂皮膜を形 成させる方法 ${ }^{2}$ なよ゙の提案もなされているが, 同様に 別工程が必要であるためコスト高であり，風合いが硬く なる，親水性の樹脂皮膜を介在させるため接着性が低下 するなどの課題が残されている。

第 2 の考え方は，コーティング樹脂中に分散染料の移 行を抑制する添加斉を配合し，樹脂膜表面への分散染料 の拡散速度を遅くしようとするものである。その 1 つの 例が，偏平な金属片を樹脂膜中に添加して分散染料の移 行を妨げる方法 ${ }^{3}$ ) である。この方法では, 分散染料が 樹脂中を，樹脂膜と平行に積層された扁平な金属片を迂 回しながら拡散するため, 樹脂表面へ到達する時間を遅 延させることができる。この効果はあくまであ遅延効果 であり, 分散染料の移行拡散を防止するものではないた め, 効果の持続性に課題が残されており, また, 溶媒中 を分散染料が拡散する乾式コーティングにはほとんど効 果が見られない。

別の方法として, 分散染料と相溶性の悪い物質を樹脂 膜中に添加して分散染料の移行を妨げる方法 ${ }^{4)}$ も提案 されているが, 原理的には樹脂中の拡散の見掛け上の遅 延効果であり，同様の課題が残されている。

第 1 の考え方に基づく方法では前処理という別工程が 必要なのに対して，第 2 の考え方に基づく方法は，コー ティング樹脂溶液中に添加剂を配合するだけで対応でき る点で大きなコストメリットがある。しかしながら，こ れまでの方法は先に述べたように樹脂膜中の分散染料の 移行拡散を抑制する効果は有するが，移行拡散を阻止す る効果は有していなかった。

筆者らはこの両者の長所を生かした第 3 の考え方とし て，樹脂膜自体を移行拡散の阻止膜とする方法を考えた。 しかし，コーティング樹脂膜全体を上述のようなメラミ ン樹脂膜としたのでは，風合い面で使いものにならない。 当初は移行阻止膜をコーティング樹脂層の間に積層する 方法あ考えたが，これでは透湿性が大幅に低下してしま う上，コストメリットあなくなってしまう。そこで思い ついたのが, 分散染料の移行阻止膜から選択吸着膜への 発想の転換である。

メラミン架橋樹脂膜による分散染料の移行拡散阻止で は，この膜が $\mu \mathrm{m}$ 以下という薄膜であるが故に，分散染 料の分子直径よりあ小さな孔径のち密膜の形成が必要で あった。ところが数 $\mu \mathrm{m}$ 数十 $\mu \mathrm{m}$ の膜厚を有するコ一 ティング樹脂膜全体で分散染料の移行拡散を阻止すると なると，必ずしもメラミン架橋樹脂膜のようなち密膜は 必要でない。分散染料が樹脂膜中を拡散する間に，これ を効果的に捕捉し，分散染料が樹脂膜表面まで到達しな ければよいわけである。

この発想から生まれたのが，樹脂中に分散染料を効果 的に吸着させる染料捕捉剤を配合する技術である。筆者

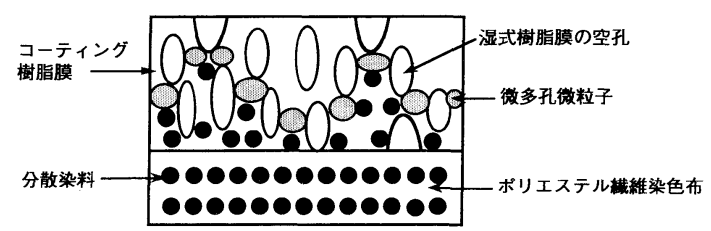

図 2 分散染料の捕捉剤として微多孔微粒子を用いた染料移行 阻止膜のイメージ図

表 1 微多孔微粒子を用いたコーティング加工布と末添加の通 常加工布との性能比較

染料移行污染防止性：130 0 C $\times 90$ 分、荷重 $4.5 \mathrm{~kg}$ (乾熱移行法)

\begin{tabular}{|c|c|c|}
\hline & 本加工品 & 通常加工品 \\
\hline 染料移行污染防止性（級） & $4 \sim 5$ & $1 \sim 2$ \\
\hline 透湿度 $\left(\mathrm{g} / \mathrm{m}^{2} / 24 \mathrm{~h}\right)$ & 8840 & 8440 \\
\hline 耐水圧 $(\mathrm{m} \mathrm{m})$ & 4000 & 3500 \\
\hline 剥離強度／タテ（g） & 1170 & 1150 \\
\hline 剥離強度／ヨコ（g） & 890 & 810 \\
\hline
\end{tabular}

らは, 分散染料を効率良く吸着し, しかも脱着しにくい 染料捕捉剤について検討を重ね, 分散染料の分子サイズ に匹敵する非常に小さい孔径を有する微多孔微粒子が有 効な染料捕捉剤となることを見出し, 湿式コーティング 用の移行昇華污染防止技術として完成させた。本技術の イメージ図を図 2 に, 性能レベルの一例を表 1 に示した が，透湿性や耐水圧，はく離強度など一般の物性に全く 影響を与えず，高い移行昇華污染防止効果が得られてい るのがおわかりいただけると思う。本技術は，すでに平 成 2 年より, 主として船積みなどで高い移行昇華污染防 止効果が必要とされる輸出用の湿式コーティング素材を 中心に展開されている。

しかしながら，先に染料移行昇華污染の機構で説明し たように，染料捕捉剤を用いるこの技術は，分散染料が 樹脂膜中を熱拡散によって移行する湿式コーティングに は適用できるが, 分散染料が溶媒中に溶解拡散して移行 する乾式コーティングではほとんど効果が見られなかっ た。

\section{4. 新しい染料移行昇華污染防止技術}

湿式コーティング用の分散染料移行昇華污染防止技術 については，その効果の程度は別として，上述の第 2 あ るいは第 3 の考え方に基づく方法で実用化が進められて きている。しかしながら，乾式コーティング用の技術之 しては，上述の第 1 の考え方に基づく方法しか有効なも のはなく，湿式コーティングよりあ低コスト化が必要な 技術分野であるだけに実用化は難しい状態にあった。

筆者らむ，上述の湿式コーティング用染料移行昇華污 


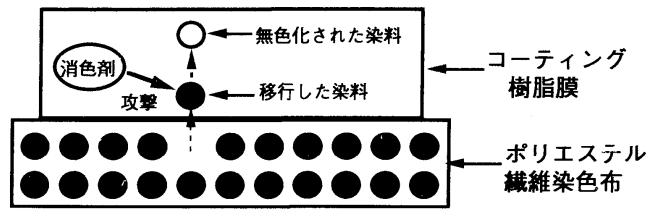

図 3 有機過酸化物による化学反応を利用して分散染料を無色 化する新しい考え方の染料移行昇華污染防止技術のイメー ジ図

染防止技術の完成の後, 乾式コーティング用の技術開発 に取り組んだが，開発当初，先の技術の成功のために染 料捕捉の考え方が頭から離れず, 溶媒中で効果的に分散 染料を吸着する捕捉剤の探索に専念していた。すなわち, 第 3 の考え方に基づく別の方法を模索していたのである。 そうした中で，ある有機金属塩が特定のキノン系染料 に対してではあるが，移行昇華污染防止効果を示すこと を見出した。効果を示す分散染料の構造か類似しており, しかも配位結合を形成できる官能基が特定の位置に存在 していたことから，有機金属塩との配位結合による染料 捕捉と考えたが，これらの分散染料を溶解させたトルエ ン溶媒中に有機金属塩を添加したところ，予想した錯体 の形成による変色は見られず, 逆に溶液は無色になった のである。

この発見を契機に，筆者らは再度発想の転換を行い， 第 4 の考え方として, 分散染料の移行昇華污染を防止す るのではなく, 分散染料を移行してあ污染しない無色の 化合物に変換する方法（図 3 ）の検討を開始した。

分散染料を無色化する方法としては，ハイドロサルファ イトによる還元洗浄がよく知られている。実際にこの還 元剤を樹脂溶液に配合して乾式コーティングを行うこと により，移行昇華污染防止が可能であったが，無色化さ れた分散染料の中には酸化されて復色するあのがあり, 何よりあイオウ臭がひどく, 実用化できるあのではなかっ た。

そこで, 酸化反応により分散染料を無色化できる酸化 剤の探索を行った。樹脂溶液中に配合するのであるから， 配合樹脂中では反応せずに安定で, 数十秒間の乾燥工程 中に反応して分散染料を無色化しなければならない。す
なわち，ポリエステル絾維布帛上にコーティングされる までは反応性を有さず，乾燥工程の熱で瞬時に，しかす 選択的に移行した分散染料と反応して無色化させる反応 剤でなければならない。したがって，ポリエステル緘維 布帛表面で, 非常に制御された条件で化学反応を行うこ とが要求されるわけである。筆者らは，このような要求 を満たす反応剤の探索を集中的に行い，この 2 つの条件 を同時に満たす酸化剂として，ある特定の有機過酸化物 が有効であることを見出し，乾式コーティング用の染料 移行防止技術として完成させた。本技術については，ま ず傘地の染料移行昇華污染防止および山ヤケ防止技術と して展開の予定である。

\section{5. おわりに}

ポリエステル繊維コーティング加工布帛の分散染料移 行昇華污染防止技術の完成は，ポリエステル繊維の研究 を行うあのにとって永年の課題であった。特に, 繊維産 業のグローバル化の流れの中で, 輸出などで問題となる この現象の解決は，必要不可欠であった。筆者らは，新 しい発想に基づく技術開発により，湿式コーティング用 の染料移行昇華污染防止技術之乾式コーティング用の技 術をそれぞれ完成させたわけであるが，その技術完成度 は100\%ではない。

冒頭にも述べたように，分散染料移行昇華污染の現象 はナイロン繊維には見られない問題である。したがって, この移行昇華污染を $100 \%$ 防止できる技術が完成されて 初めて，コーティング加工布帛としてポリエステル纎維 がナイロン緘維と対等に勝負できるようになるのである。 コーティング加工の世界において，今後一層ポリエステ ル化を促進させるためにす，さらに性能の向上に努めて いきたい。

(1995-7-6 受理)

\section{文献}
1) 風 正公 (小松精練); 特開昭 59-82469（1984）
2 ) 関本雅章（北日本染工）; 特開昭 60-39479（1985）
3) 関本雅章（北日本染工）; 特開昭 60-45680（1985）
4 ）赤木孝夫（クラレ）；特開昭 62-45784（1987） 